\title{
Utilization of extracted substance from Indian almond leaves, Terminalia catappa $L$. for preparation of folk medicinal cream for the use of skin protection
}

\author{
P. Muangthai*, P. Chawenggrum and W. Khunwarakul \\ Department of Chemistry, Srinakharinwirot University, 114 Sukhumvit 23 , Bangkok city, THAILAND \\ *Corresponding Author. E-mail: pornpim20@gmail.com \\ Received: February 12, 2015; Revised received: March 12, 2015; Accepted: March 20, 2015
}

\begin{abstract}
The aim of this work was to study the method to prepare the folk medicinal cream for the use of skin protection from the extracted substance of Indian almond leaves, Terminalia catappa L. in 4 periods as young green leaf , mature green leaf, orange red leaf and brown leaf by 4 methods. Tannic acid was the key index in preparation ,and tested by TLC and quantized its content. $\beta$-carotene was also TLC test in quality check. The study showed that the brown leaves sample treated by heating at $100^{\circ} \mathrm{C}$ for 5 minutes and continue fermentation for 21 days, gave the extracted solution that contained highest tannic acid approximately as $80 \mathrm{mg} / 100 \mathrm{~g}$ and was considered the best one. The extracted solution was used as one ingredient in folk cream. In this work, the four formulations with variation of extracted solution were studied and analysed total phenolic compound, tannic acid and antioxidant inhibition power. The cream with more extracted substance showed total phenolic compound, tannic acid more than those fewer content of extracted substance. This work found that the skin cream protection with antioxidation substance could made from extracted substance of Indian almond leaves.
\end{abstract}

Keywords: Extracted substance, Folk medicinal cream, Indian almond, Tannic acid

\section{INTRODUCTION}

Indian almond has an scientific name as Terminalia catappa L.(Thomson and Evans, 2006). Its leaves contain many phytochemical substances. Tannic acid is the one phytochemical compound in Indian almond leaf (Lin Hsu and Chen Lina, 1999). Tannic acid is an organic acid substance and also a soluble polyphenolic substance (Suganda et al., 2006). It is widespread used as clarification agent in beer industry and aroma compound in soft drink and juices(Nwachukwe and Umechurma, 2001). FDA recognizes tannic acid as a safe substance (Harold et al., 2007), so it is also uses as meditation application which depend on its biological activity (Masuda et al., 1999) such as cytotoxicology (Chen et al., 2000), anticancer (Chu,et al.,2007), antidiabetics (Nagappa et al.,2003), anti HIV(Tan et al.,1991), antitussive, laxative , diuretic, cardiotonic activities (Ratnasooriya and Dharmasiri, 2000 ; Sahil, 2010) . There are many works that report the application of Indian almond leaf as folk medicine such as fallen leaves were used as herb to treat liver disease (Lin et al., 1997), fish pathogen (Shikha et al., 2013). The other substance such as beta-carotene which was an important in many plants since its gave a brightness orange color in plant (Umale and Mahanwar, 2012). This pigment is generally found in yellow or orange leaf or fruit of plant but not referred in Indian almond leaf. However, there was no report about the application of Indian almond leaf to made medicinal cream. The aim of this work was to study the method to prepare the medicinal cream of the extracted substance from four periods of Indian almond leaves such as young pale green leaf, mature green leaf, yellow red leaf and brown leaf and also to analyze for tannic acid and $\beta$-carotene .

\section{MATERIALS AND METHODS}

Material : All chemicals in this work were AR grade. Folin Ciocalteau reagent, 1,1-Diphenyl-2 picrylhydrazyl , sodium carbonate ,gallic acid, tannic acid, beta-carotene were purchased from sigma chemical (USA). Methanol, ethanol, diethyl ether, n-hexane and chloroform were purchased from Carlo Erba Reagents. Glacial acetic acid was purchased from Quality Reagent Chemicals. Raw material and cream ingredient such as glycerin, glydant plus, tween 20, AP wax80, stearic acid , cetryl alcohol, white oil were cosmetic grade from Chemipan coporation, Thailand. TLC plate (siliga gel $\left.60 \mathrm{~F}_{254}\right)(25$ Aluminium sheets $20 \times 20 \mathrm{~cm}$ ) commercial plate was purchased from Merck).

Plant sample: The leaves of Indian almond in each period such as young pale green leaf, mature green leaf, red orange leaf and brown leaf were collected from garden house inside Srinakharinwirot University and Ramkhamkheang University, in August to September 2014 were taken .

Methodology:

Part 1. Preparation of sample for Tannic acid analysis: The leaf samples of each period was approximately 
weighed 10.xxxxg, crushed into small piece and treated by the 4 treatments method as the following: Treatment method1: The leaf sample was placed in 50 $\mathrm{ml}$ of water (Chansue and .Assawawongkasem, 2008) Treatment method 2: The leaf sample was boiled with water at $100{ }^{\circ} \mathrm{C}$ for 5 mins.

Treatment method 3: The leaf sample was placed in 50 $\mathrm{ml}$ of water and ultrasonication for 5 mins.( Chyau et al., 2006 )

Treatment method 4: The leaf sample was placed into $50 \mathrm{ml}$ of ethanol.

The residue leaf from each treatment was filtered out and collected the filtrate to study in the next part.

The leaves were treated as the methods that gave the highest tannic acid content and kept at room temperature for 2 months and the filtrates were analysed in the period of $7,14,21,30$ and 60 days.

Part 2.Qualitative determination of tannic acid and beta-carotene in filtrate plant leaves: Standard solution of tannic acid, gallic acid, and beta-carotene were prepared as $500 \mathrm{ppm}$ and spot on siliga gel $60 \mathrm{~F}_{254}$ aluminium plate. The filtrate from extractant sample was also spot in the same plate. The ready spot plate was placed into the chromatographic tank that contained the mobile phase solvent(Harborne, 1989) as:

System 1: methanol - diethyl ether - water (56:40:5) System2: chloroform - methanol - acetic acid (90:10:1) Then the analyte on the chromatogram was detected by spraying agent as $1 \%(\mathrm{v} / \mathrm{v})$ folin ciocalteau reagent and $5 \%(\mathrm{w} / \mathrm{v})$ sodium carbonate.

Part 3. Quantitative determination of tannic acid and beta-carotene in filtrate plant leaves.

3.1. Preparation of standard calibration curve (modified from Pelozo et al., 2008): The standard tannic acid solution was prepared as $20-100 \mathrm{ppm}$ and then pipette $0.5 \mathrm{ml}$ of each standard solution mixed with $0.5 \mathrm{ml}$ of $10 \%$ Folin Ciocalteu Reagent and 5 ml. of $20 \% \mathrm{Na}_{2} \mathrm{CO}_{3}$ and vortex (Sciencetific Industries) mixed $1 \mathrm{~min}$. The mixed solutions were kept at room temperature for 30 mins. before absorbance measurement at $735 \mathrm{~nm}$ by Ultraviolet Visible Spectrometer( UV -VIS Shimadzu Model UV100). The absorbance of each standard tannic acid solution was plotted with its concentration to construct the standard calibration curve.

The standard $\beta$-carotene was prepared as 5-100 ppm and recorded an absorbance at $453 \mathrm{~nm}$. Then the calibration curve was also plotted as a standard calibration curve.

3.2. Measurement of tannic acid and $\beta$-carotene in sample filtrate: The filtrate $(0.5 \mathrm{ml})$ of leaf samples from part 2 were pipetted and treated as mentioned in part 3.1. The complex color solution was recorded an absorbance and compared with the standard calibration curve to calculate the tannic acid content.

Another $10.00 \mathrm{~g}$ of the leaves samples were saponified by $5 \mathrm{ml}$ of $50 \% \mathrm{KOH}$ and $50 \mathrm{ml}$ of $95 \%$ ethanol with heating at $80{ }^{\circ} \mathrm{C}$ for 30 mins. Then the filtrate was extracted with $5 \mathrm{ml}$ of $\mathrm{n}$-hexane for 3 times and the colored sample in hexane layer was separated and measured an absorbance at $453 \mathrm{~nm}$. The $\beta$-carotene in sample was calculated by comparison with standard calibration curve of $\beta$-carotene.

Part 4. Preparation of folk medicinal cream: The folk medicinal cream was prepared for variation of extracted solution from part 2, that gave the highest tannic acid content as the following cream formulation, modified from Wolverton (2001).

F1 : cream base ( no extracted solution)

F2: cream base with water : extracted solution (40:20)

F3: cream base with water : extracted solution $(20: 40)$

F4: cream base with water : extracted solution $(0: 60)$

Note : Cream base formula compose of water $(60 \mathrm{~g})$, glycerin( $8 \mathrm{~g}$ ), glydant plus( $0.4 \mathrm{~g})$, tween 20 (12.5 g), AP wax $80(1 \mathrm{~g})$, stearic acid $(5 \mathrm{~g})$, cetryl alcohol (4 g), white oil (4 g), and vitamin E (0.01 g)

Part 5. Analysis of total phenolic content, tannic acid, antioxidant inhibition power in medicinal cream samples

5.1 Analysis of total phenolic content: The analytic method modified from Pelozo et. al.,(2008) was used. The clear filtrates from part 2. were pipetted $0.4 \mathrm{ml}$ and mixed with $2 \mathrm{ml}$ of $10 \%$ Folin Ciocalteau reagent and $1.6 \mathrm{ml}$ of $7.5 \%(\mathrm{w} / \mathrm{v}) \mathrm{Na}_{2} \mathrm{CO}_{3}$ and left at room temperature for 30 minutes. The mixing solution was measured an absorbance at $765 \mathrm{~nm}$ by Ultraviolet Visible Spectrophotometer (UV-VIS Shimadzu Model UV100) and calculated total phenolic compound content as gallic acid equivalent by comparison with standard calibration curve. The samples were treated as above and also calculated total phenolic content as gallic acid.

5.2 Analysis of antioxidant inhibition power ( $\mathrm{Li}$ et al., 2007). The clear filtrate from part 2 were pipetted $600 \mu \mathrm{L}$ mixed with $600 \mu \mathrm{L}$ of $0.1 \mathrm{mM}$ DPPH then measured an absorbance of the complex color from the reaction at $517 \mathrm{~nm}$. The inhibition power was calculated by comparing with standard BHT.

5.3 Analysis of tannic acid content : Do the experiment as in part 3.

Statistical Analysis: All determinations were carried out at least in five replication and values were averaged. The results are expressed as mean \pm S.D. values, statistical differences between means were determined by one way ANOVA. Microsoft Excel were used for calculate and graph presentation in this work.

\section{RESULTS AND DISCUSSION}

In preparation of extracted solution from each period of Indian almond leaves by 4 treatment methods, the quality check for the present of tannic acid, gallic acid, $\beta$-carotene revealed that the development chromatogram by using mobile phase solvent 1 could separate tannic acid, gallic acid , $\beta$-carotene better than mobile phase system2. The example of chromatogram (Fig.1) showed the different $\mathrm{Rf}$ value of three standards substance (Table. 1). 
Table 1. Rf values of extracted solutions.

\begin{tabular}{lc}
\hline Substance & Rf value \\
\hline$\beta$-carotene & 0.85 \\
Gallic acid & 0.56 \\
Tannic acid & 0.25 \\
Extracted sample & 0.25 \\
\hline
\end{tabular}

Table 2. Qualitative check for tannic acid and $\beta$-carotene

\begin{tabular}{lcc}
\hline Leaf period & Tannic acid & $\begin{array}{c}\boldsymbol{\beta}- \\
\text { carotene }\end{array}$ \\
\hline Young pale green leaf & + & - \\
(S1) & + & + \\
Mature green leaf (S2) & + & - \\
Red orange leaf (S3) & + & - \\
Brown leaf (S4) & + & - \\
\hline
\end{tabular}

Note: + present could be detected; - present could not be detected

The quality check in extracted solution from each period leaves showed presence of tannic acid in all leaves samples but some samples showed a pale spot of $\beta$-carotene (Table 2). This indicated that $\beta$-carotene could be detected in some period of Indian almond leaf such as mature green leaf.

The extracted solution from 4 treatment methods were analysed for the quantity of tannic acid and the results showed that after applying of 4 treatment methods (Fig.2), the method 2 (boiled with water for 5 minutes) trended to extract the highest quantity of tannic acid from all leaves samples. This may result from the heating that could breakdown the structure of tannic acid from cellulose better than the other method as report (Charng et al., 2002). The analysis results from $\beta$-carotene content in each extracted samples by treatment method 2 (Fig. 3) gave the positive result (Table 2). The mature green leaf contained the highest $\beta$-carotene content in both treatment method 2 and method 4 as $75.64 \pm 11.23$ and $717.75 \pm 55.22 \mu \mathrm{g} / 100 \mathrm{~g}$. The method 4 was suitable for extracted $\beta$-carotene in Indian almond leaf since the leaf passed the alkaline hydrolysis step and $\beta$-carotene more dissolve into ethanol than in water. This is the reason that $\beta$-carotene nature has the conjugated double bond in its structure showed non polarity property(Chyau et al., 2007) that dissolve in non polar organic solvent better than in water. However,

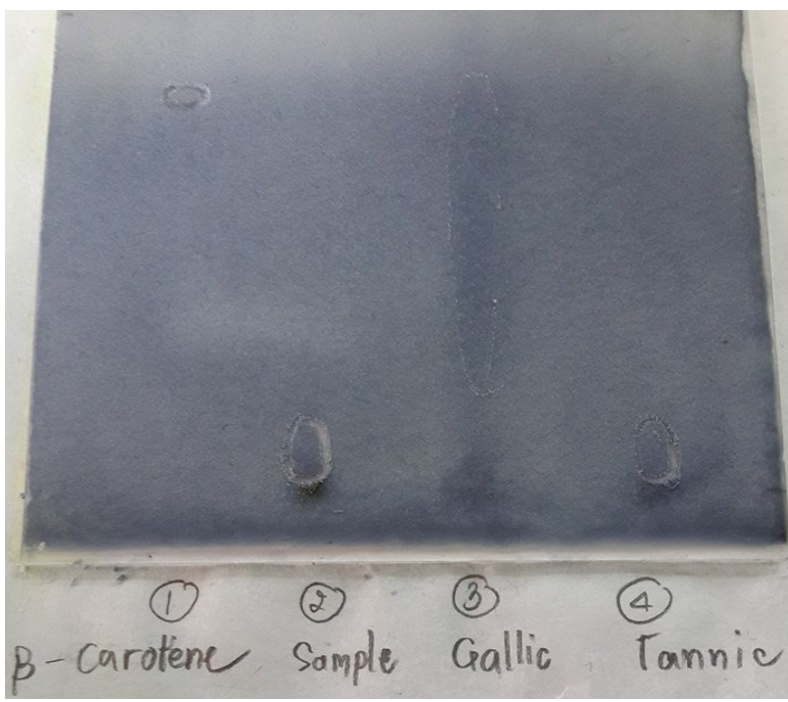

Fig.1. Chromatogram of extracted sample from Indian almond leaf compared with standard compound.Note: lane 1 represent as standard $\beta$-carotene ; lane 2 represent as extracted sample Lane 3 represent as standard gallic acid ; lane 4 represent as standard tannic acid

this work concentrated on tannic acid content thus tannic acid was the index indicate for further experiment. The treatment method 2 would be use for try in next part. However, the leaves samples were studied the effect of fermentation the sample for 2 months by treatment method 2 and revealed (Fig. 4) that the extracted solution from different period of leaves that treated by boiling leaves samples for $5 \mathrm{~min}$ and fermented for 21 days gave the highest quantity of tannic acid but after 30 days of fermentation tannic acid content trend to decrease (Okuda et al., 1986). Indian almond leaves release tannic acid to the water since the leaf structure almost destroy depend on time that it placed in medium (Chitmanat et al., 2005). The extracted solution from the brown leaves or fallen leaves showed the highest tannic acid at 21 day of fermentation, and the result support the experiment of Charng-Cherng Chyaua et al. (2002) that brown leaves or fallen leaves immesed in water contain important phenolic compound.

The folk medicinal cream which was prepared for 4 formulations and the extracted substance from fallen leaves was the one composition in cream and variation ratio of water content in cream (Fig. 5). The physical characteristics of folk cream showed more deep brown

Table 3 Chemical properties of folk medicinal cream (Mean \pm SD of 5 replicates ).

\begin{tabular}{lccc}
\hline Cream types & $\begin{array}{c}\text { Tannic acid content } \\
(\mathbf{m g} / \mathbf{1 0 0 g})\end{array}$ & $\begin{array}{c}\text { Total phenolic content } \\
(\mathbf{m g} / \mathbf{1 0 0 g})\end{array}$ & $\begin{array}{c}\text { \% antioxidant inhibition } \\
\text { power }\end{array}$ \\
\hline F1 & $1.46 \pm 1.69$ & $13.09 \pm 6.81$ & 1.20 \\
F2 & $5.02 \pm 0.66$ & $67.27 \pm 7.20$ & 90.10 \\
F3 & $8.15 \pm 1.11$ & $131.21 \pm 7.48$ & 84.78 \\
F4 & $13.92 \pm 0.75$ & $181.02 \pm 6.39$ & 78.02 \\
\hline
\end{tabular}




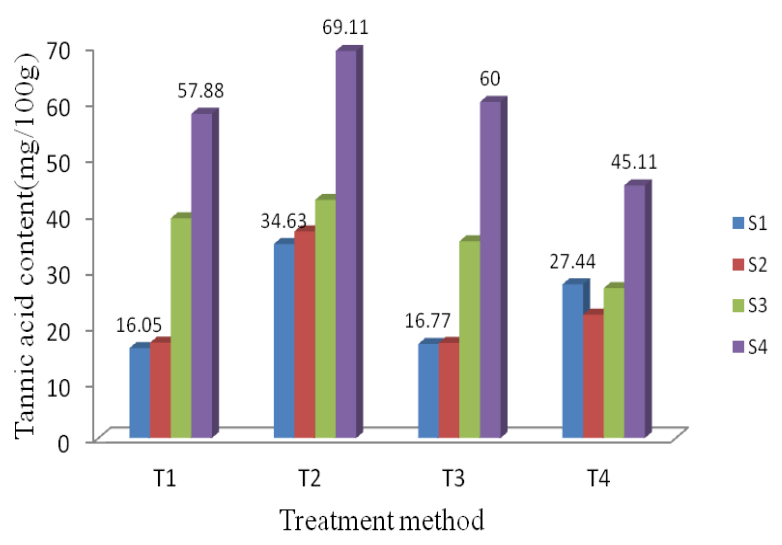

Fig.2. Tannic acid content in extracted solution from different



Fig.3. $\beta$-carotene content in extracted solutions from the method 2 and 4

color when extracted solution in cream increase, F4 showed the deepest brown. The results of testing quality content of total phenolic compound, tannic acid and antioxidation inhibition power (Table 3 ) were between $67.27 \pm 7.20-181.02 \pm 6.39 \mathrm{mg} / 100 \mathrm{~g}, \quad 5.02 \pm 0.66-13.92$ $\mathrm{mg} / 100 \mathrm{~g}$ cream and $1.20-90 \%$, respectively. It was noticed that F1 which was cream base showed a lowest content of both parameter and also lowest of $\%$ antioxidant inhibition power as $1.20 \%$. However, total phenolic compound content related with tannic acid content which showed the same trend, and both parameters showed the highest content in F4. The \% antioxidant inhibition power trend to decrease when total phenolic compound and tannic acid content increase.

After using the extracted solution in F2 for prepare folk cream, tannic acid in F2 about $4.91 \mathrm{mg} / 100 \mathrm{~g}$ showed the highest antioxidant inhibition power. As the physical characteristic (Fig.4) F2 cream also best physical cream, nice color too. However, if using the extracted solution maximum as F4, its gave the maximum content of total phenolic compound and tannic acid but it showed the deepest brown color.

\section{Conclusion}

This work showed that an Indian almond leaves in 4 period as young green leaf, mature green leaf, red orange leaf and brown leaf or fallen leaf contained a difference quantity of tannic acid in extracted solution.

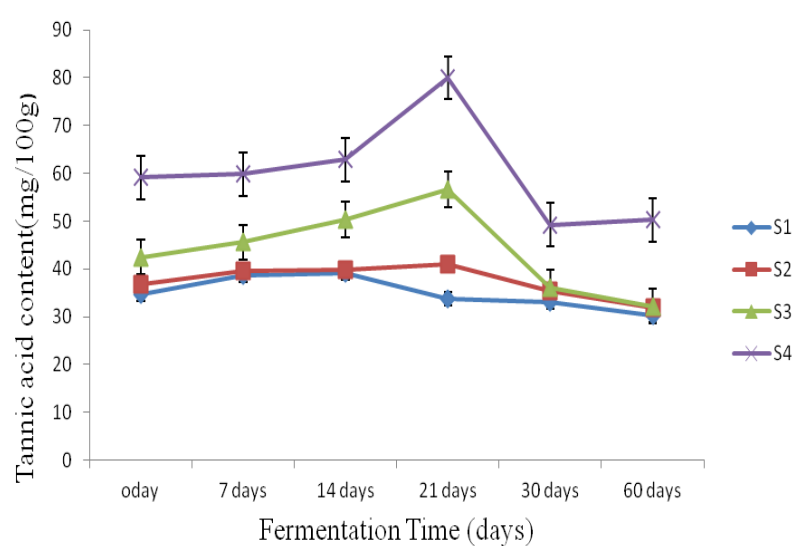

Fig. 4. Tannic acid content in extracted solution from Indian almond leaves in variation fermentation times.

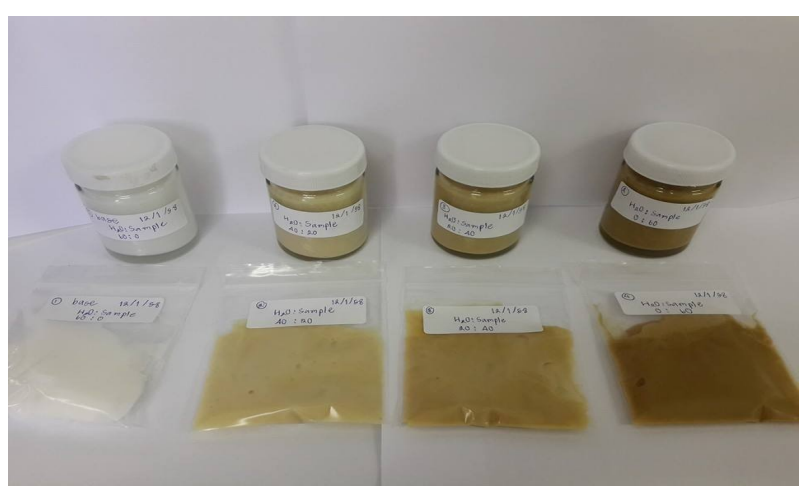

Fig. 5. Folk medicinal cream from Indian almond leaves

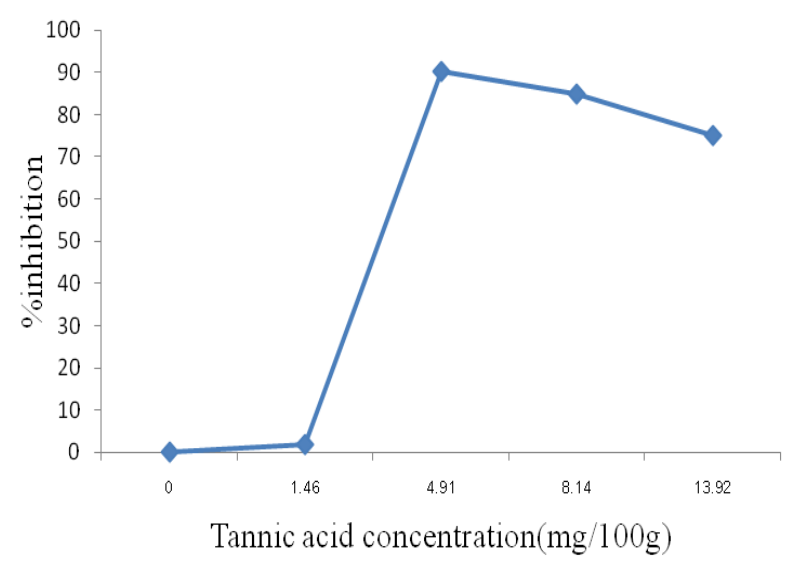

Fig. 6. Relationship between tannic acid content with \% antioxidant inhibition power.

Tannic acid and $\beta$-carotene in extracted solutions could be rapidly detected by TLC. In the analysis of tannic acid by treatment method 2 (boiling in water 5 minutes), the brown leaf or fallen leaf showed the highest tannic acid content as $69.11 \pm 5.12 \mathrm{mg} / 100 \mathrm{~g}$. In study fermentation time for 60 days revealed that tannic acid in almost leaves samples decrease after 21 days of fermentation, and brown leaf contained highest tannic acid content approx. $80 \mathrm{mg} / 100 \mathrm{~g}$. In preparation of folk medicinal cream as 4 formulations which were analysed phytochemical compound as total phenolic compound, tannic acid and antioxidant inhibition power found that F4 cream 
showed the highest total phenolic compound as 181.02 $\pm 6.39 \mathrm{mg} / 100 \mathrm{~g}$ and tannic acid as $13.92 \pm 0.75 \mathrm{mg} / 100 \mathrm{~g}$ and $75 \%$ of antioxidant Inhibition power, this was the best formulation. This work proved that the extracted substance from the brown color Indian almond leaves could be effective in making folk medicinal cream which contained phytochemical substances and may be used for skin protection .

\section{ACKNOWLEDGEMENTS}

Our team wishes to Thank the Strategic Wisdom and Research Institute Srinakharinwirot University for supporting the budget money from Annual income of University for 2014.

\section{REFERENCES}

Chansue, N and Assawawongkasem, N. (2008). The in vitro antibacterial activity and ornamental fish toxicity of the water extract of Indian almond leaves (Terminalia catappa Linn.). KKU Veterinary Journal , 18 (1): 25-30.

Charng-Cherng Chyaua, Shu-Yao Tsaib, Pei-Tzu Kob, Jeng -Leun Maub. (2002).Antioxidant properties of solvent extracts from Terminalia catappa leaves. Food Chemistry. 78: 483-488.

Chen. P.S., Li.J.H, Liu .JY. and Lin.TC. (2000). Folk medicine Terminalia catappa and its major tannin component, punicalagin, are effective against bleomycin induced genotoxicity in Chinese hamster ovary cells. Cancer Letters .52: 115-122.

Chitmanat, C, Tongdonmuan.K and Nunsong.W. (2005). The use of crude extracts from traditional medicinal plants to eliminate Trichodina $s p$. in tilapia (Oreochromis niloticus) fingerlings. Songklanakarin Journal of Scence and Technology. 27: 359-361.

Chu, S.C., Yang. S.F., Liu. S.J., Kuo. W.H., Chang. Y.Z and Hsieh. Y.S. (2007). In vitro and in vivo antimetastatic effects of Terminalia catappa L. leaves on lung cancer cells.Food and Chemical Toxicology .45: 1194-1201.

Chyau, C.C., Ko, P.T. and Mau. J.L. (2006). Antioxidant properties of aqueous extracts from Terminallia catappa leaves. LWT - Food Science and Technology. 39(10): 1099-1108.

Harborne, J.B. (1989). Methods in plant biochemistry. Vol1. Academic press.

Harold, Kalant, Grant, Denis M, Mitchel and Jane (2007). In: Principles of medical pharmacology. Seventh Edn. Elsevier Canada Ltd. 557-559 pp.

Li, H.B, Cheng, K.W., Wong, C.C., Fan, K.W., Chen, F and Jiang.Y.(2007). Evaluation of antioxidant capacity and total phenolic content of different fractions of selected microalgae. Food Chemistry. 102: 771-776.

Lin, C.C., Chen, Y.L., Lin, J.M. and Ujiie, T. (1997). valuation of the antioxidant and hepatoprotective activitiy of Terminalia catappa. The American Journal of Chinese Medicine . 25: 153-161.
Lin Hsu, F. and Chen Lina, T. (1999). Tannin and Related Compounds from Terminalia catappa and Terminalia parviflora, Journal Chinese Chemical Society.46 (4): 613-618.

Masuda, T. Yonemori, S., Oyama. Y., Tekeda, Y., Tanaka, T, Andoh. T., Shinohara, A. and Nakata, M. (1999). Evaluation of the antioxidant activity of Environmental plants activity of the leaf extracts from sea shore plants. Journal of Agricultural and Food chemistry. 47: 1749-1754.

Nagappa, A.N., Thakurdesai, P.A., Venkat Rao. N. And Singh, J. (2003). Antidiabetic activity of Terminalia catappa Linn fruits. Journal of Ethnopharmarcology. 88: 45-50.

Nwachukwe, E.O. and Umechurma, C.I. (2001). Antifungal Activities of Some Leaf Extracts and Seed Borne Fungi of African Yam Bean Seeds, Seed Germination and Seed-ling Emergence. Journal of Applied Science and Environmental Management, 5(1): 29-32.

Okuda, T, Hatano, T., Agata, I. and Nishibe, S. (1986). The constituents of tannic activities in labiatae plants. I. Rosmarinic acid from labiatae plants in Japan. Yakugaku Zassh.106: 1108-1111.

Pelozo, M.I.G., Cardoso. M.L, C.and Mello, J.C.P. (2008). Spectrophotometric determination of tannins and caffeine in preparations from Paullinia. cupana var. sorbilis. Brazilian Archives of Biology and Technology. 51: 447-451.

Ratnasooriya, W.D. and Dharmasiri, M.G. (2000). Effects of Terminalia catappa seeds on sexual behavior and fertility of male rats. Asian Journal of Andrology. 2: 213-266.

Sahil, T. (2010). Anti-inflammatory activities of Terminalia paniculata bark extract against acute and chronic inflammation in rats. Journal of Ethnopharmacology. 134(2): 323-328.

Shikha, M., Renu, M., Ranjana, V. Shubhangi, M. and Rajshree. S. (2013). Phytochemical analysis of the leaf extract of Terminalia catappa L Indian Journal Applied \& Pure Biology. 28(1): 65-70.

Suganda, A.G., Sukandar, E.Y. and Ratna, L. (2006). Aktivitas antimikroba ekstrak etanol daun dua belas jenis tumbuhan marga terminalia (Combretaceae), ACTA Pharmaceutical Indonesia. , XXXI (1): 18-23

Thomson, L.A.J. and Evans, B. (2006). Terminalia catappa (tropical almond), ver. 2.2. In: Elevitch, C.R. (ed.). Species profiles for Pacific island agroforestry. Permanent Agriculture Resources (PAR), 250pp.

Tan, G.T., Pezzuto, J.M., Kinghorn, A.D. and Hughes, S.H. (1991). Evaluation of natural products as inhibitors of human immunodeficiency virus type 1 (HIV -1) reverse transcriptase. Journal of Natural Products .54: 143-154.

Umale, S. and Mahanwar, P.A. (2012). Extraction of colorant from leaves of Terminalia catappa using Non conventional technique. International Journal of Basic \& Applied Sciences IJBAS-IJENS. 12 (1): 79-88.

Wolverton, S.E. (2001). Comprehensive dermatologic drug therapy. WB Saunders. 